QIJIS : Qudus International Journal of Islamic Studies

Volume 7, Number 1, 2019

DOI : 10.21043/qijis.v7i1.4365

\title{
CONTESTING SACRED ARCHITECTURE: \\ POLITICS OF 'NATION-STATE' IN THE BATTLES OF MOSQUES \\ IN JAVA
}

Achmad Fawaid

Nurul Jadid University

fawaidachmad@unuja.ac.id

Zamroni

IAIN Samarinda, Borneo, Indonesia

zamroni@iain-samarinda.ac.id

Hasan Baharun

Nurul Jadid University

ha54nbaharun@gmail.com

\begin{abstract}
This study aims to figure out a 'political' contestation of sacred mosques in Java and the ways the Javanese respond to the global architecture of the Middle Eastern Islam. By using a historical narrative method, this article describes a fact that some 'sacred' architectures which shaped from the national mosques became a site of battles between the modern Islamic and traditional Javanese worldviews and explores the continuum debate over architecture, culture, and power of Islam in Java through various events since the fifteenth until today. This study, finally, results in the issues related to not merely the almost unsolved dispute over modern and traditional architectures, between pan-Islamic modernists and Javanese traditionalists, but most importantly, the past stories and silent ideology behind the
\end{abstract}


building of these mosques, and by doing so, it also questions our primordial understanding of nation-state.

Keywords: Islam; Java; mosques; architecture

\section{A. Introduction}

For many years, architecture has been regarded as a form of dominance and political strategy of colonialism. Much attention is given to the inseparable relation between architecture and politics, and between agency, ideology, and history. Many incredible works are available for discussing the important discourse of such relationship partly in postcolonial society (Al-Sayyad, Nezar, 1992); (Anthony D King, 1976); (Gwendolyn, 1991); (Waterson, 1997); (Hasan, 2009). The fact that postcolonial regions received politics of architectures in different ways and times has some impacts on the interpretation of their idea of nationalism, for they have a political strategy of negotiation in dealing with the cultural flow of architecture from Europe or Middle East. The rich discussion on relationship between architecture, politics, and culture reveals how important this field of analysis in the current interpretation of our nation-state is (for instance, (Kusno, 2000); (Kusno, 2003); (MacRae, 2011); (Nas, 2003); (Sharif, 2013).

There are lots of studies that focus on forms of architecture as dominance (Brenda, 1996); (Al-Sayyad, Nezar, 1992). Their main themes are among others related to global occupation of Middle East styles on the modern architecture in large scale of Java. Some studies attempt to figure out the huge impact of mixed styles from Europe, Latin America, and Middle East on the urban design of today's Indonesian architectures. However, there are rarely discussions on the ways architecture gets an intimate relation with the site of power in different communities in various parts of the world. Also, a problematic relationship between two big 'ideologies', East and West, is wildly an important issue among these current stud- 
ies. These studies commonly perceive an 'emergency' situation in which the various mutually constitutive power relations have been made among elements within, or internal to, one of these entities.

The most vernacular prototype in the early mosques in Java is a tajug or the long-roof house architectures, especially during the 15th and 16th century. This prototype demonstrates the continuity of ancient building practices in its ornament, placement, and design. It represents their archetypal structures and memories adapted to suit the local values. The tajug style is commonly retrieved from the liturgical references to many Hindu-Buddhist temples, but such a design adequately meets the requirements of the 'house of Allah' (Sharif, 2013 : 568) by changing the mosque building into a place for comfort and retreat.

This character is well demonstrated in Demak Mosque, which displays various forms, both in elevation and plan, for the main prayer hall (square plan), the minaret (octagonal floor plan, but it is optional), the serambi (rectangular floor plan), and several wakafs located in its compound. However, Demak Mosque is constructed under the long dispute between walis. The dispute is about whether the mihrab should be directed to Mecca or northwest. In one side, mosque is representation of Muslim spritual practice, but Demak is a site where the Javanese people have their own values.

In the early 19 th and late 20th century, the colonial rule completed their regime of the Javanese terriories. Under the colonial policy, the architectural identity was created for the indigeneous Javanese people-'an architecture that restored the colonial image as the sponsor of prosperity, peace, progress and achievement' (Sukada, $1999 ; 120$ ), and the outcome was emergence of a 'Middle Eastern Dome'. Over time, the dome has been accepted as a symbol of a mosque (Sharif, 2013 : 593). The dominance of European taste of Middle Eastern dome has a significant impact on the style and taste of ordinary Muslims in Java. 
The Istiqlal Mosque built in 1961 and finished in 1978 is commemorated as the identity of a new nation and the projection of new Islamic expression during Soekarno era. Soekarno introduces the mosque to the international world as a projection of national identity. However, five years after constructing the Istiqlal Mosque, a Javanese architect Mintobudoyo built a traditional Javanese mosque around Taman Sari Yogyakarta based on the Javanese values: one major post (Soko Tunggal), four branches, four corners, and directing the mosque to the East. For Mintobudoyo, any violation to these values is regarded as violation to the Javanese one.

Criticizing Soekarno's vision, Soeharto's New Order returns the pyramidal mosque as commemoration of the venerated Wali Songo in order to evoke the collective memory of the people with regards to ancestral practices. Morever, in 1982, he founded Yayasan Amalbakti Muslim Pancasila (YAMP), which, among its main objectives, had the goal of building mosques across the Indonesian archipelago in the form of the tajug prototype, for the form serves as a reference to the deeds of the Wali (Dijk, 2007: 65).

However, some people resisted the constructing mechanism of Masjid Amal Bakti (later known Masjid Pancasila), seen as a means of exerting totalitarian control over the masses through salary deduction policy (Santoso, 2000). Also, a certain religious organization protested the style of Demak Mosque since it was inspired from Hindu-Buddhist monument. During Soeharto's era, contesting the mosque also occured when some intellectuals disagreed on building the Nasional University mosque, because it was rooted from the temple elements. In response to this, Sutan Takdir Alisyahbana, rector of Nasional University revised his decision on building that mosque.

During the Reform Era, contesting 'Islamic', 'Javanese', or 'National' identity strongly persisted. , for instance in the construction of the Daan Mogot or Hasyim Asyari Mosque. It was contested among the Muslim people, for its construction is similar to Chris- 
tian Cross and is constructed under the idea of former Christian governor, Basuki Tjahya Purnama or 'Ahok'. Even though the Daan Mogot architect has elaborated and clarified its vision, ornaments, and placement of the sacred architecture, a dispute among the people never ended. The contested idea of whether the mosque would be like Islamic, Javanese, or 'Christian' one represented the high scaled politics of identity after Soeharto's fall.

Ironically, the ways a sacred architecture, like mosques as mentioned before, is contested for the sake of 'national' identity by referring to 'local' Java or 'global' Islam are rarely under discussion. The main objective of this study is to challenge the existence of mosques as 'sacred' canopy in relation to architecture, power, and culture. By using mosques as starting-point, this article aims to examine the high tension of inter-Islamic communities over the Islamic architecture and Javanese culture of Indonesia form pre-colonial (1498) to post-colonial (2017) period. The mosque buildings in Java are highlighted by the less conventional view of the relationship between architecture, culture, and power. Instead of focusing on the global spread of Islam and its effect on Islamic architecture in Java, I consider the way in which Java conceives of, or responds to, the global cultural flow of Islam. Consequently, the architecture is positioned as a site of negotiation and contestation between the global Islam and Javanese worldview. Based on this perspective, this article leads to the larger issues on the criticism of nation-state; how nationalism should be viewed in terms of relationship between architecture, culture, and power. It also reveals a silent ideology behind the Indonesian architecture, especially, from the sacred buildings like mosques.

\section{B. Method}

There are some conceptual terms that are used to introduce a larger framework of this paper, and to appear unspoken idea of that terms. Java is chosen as a central place of this paper, for 
it is where the capital city of Jakarta is located. In Java, the story of different people with different ethnicities are documented very well in many old manuscripts, including Babad. Java is also considered the most populous island of Indonesia. By using chronological time, this study attempts to capture the linearity of historical events of Java, and it aims to make our memories of Java could be tracked very well. This article is not at stand to understand the contribution of Islam and Java to each other, but what each of these terms means to each other as they communicate through architectural discourses.

\section{Theoretical Framework}

\section{In-between Relation: Architecture, Culture, and Power}

The Dutch colonial arrived at the Indonesia Archipelago for the first time in Java, and it shaped a considerable relation between indigenous people and colonizers, a condition in which the first anti-colonial nationalist sentiments in the early twentieth century were shaped. The most key players in political government also took place in this island where almost all of the other islands were coordinated. This island is a 'natural child' of modernity, but also represents a complicated scene of violence that has occurred throughout the life of the nation. It is not surprising that Java is a center of repertoire which provides cultural, political, and historical landscape of Indonesia. For the purpose of this paper, Java is used interchangeable with Indonesia, even though this assumption is problematic. Java, at least under the Soeharto regime (1965-1998), has stretched its culture to cover the vast space of the Indonesian archipelago.

The period which is used to represent the timing-back-forward of this paper is ranging from the pre-colonial (1498), colonial (1830), and the post-colonial (1945-2017) eras, but I prefer to think of the time period less a chronology than as a moment of return, reconfiguration, and shifting of culture and identity. How- 


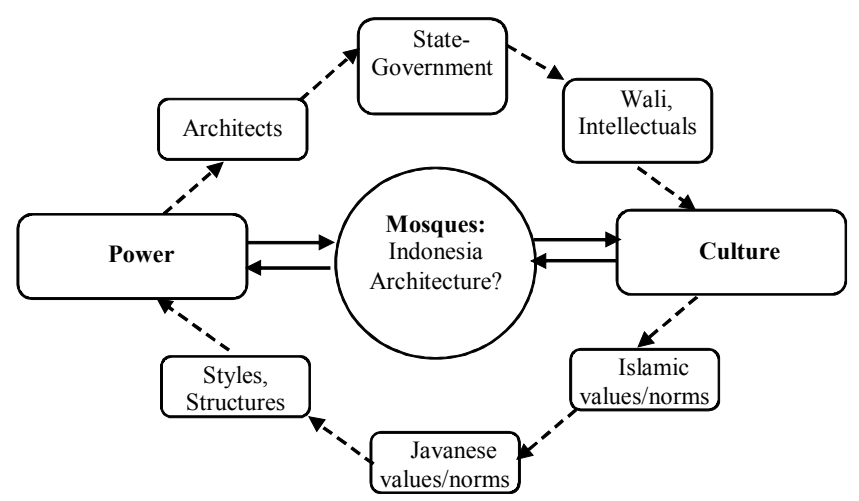

Figure 1: Contesting National Identity in-between Power and Culture of Mosques Architectural Battle

ever, by loosing time from memories of Java, it assumes that Java is highlighted in terms of difficulty of transformation, an expression of which, quite often, is the essentialization of Java itself. Instead of essentializing Java, this article attempts to get rid of it by providing ungrounded story, memory, and event of complex relationship between culture, politics, and power in the mosque architectures in Java. Dis-esentialization is a kind of cultural strategy specifically in postcolonial area to indicate cultural resilience and survival of Indonesia in the rapid historical change of the world.

Since the relation between culture, politics, and power is predominantly highlighted in this paper by showing the silent ideology of sacred architectures, this study emphasizes a term of architecture in less common terminological definition. The recent works that focus on relationship between politics and architecture in terms of urban design, among others, is Bagoes Wiryomartono, "The Politics of Development in Indonesia: The Aesthetic Culture and Power Play in Architecture and Urban Design" (2012). When architecture is positioned in a particular place and time, for instance, it refers to a reflection of the culture of society, and represents unsettling negotiations of culture and identity. The architecture, for that purpose, is regarded as a site of negotiation where it was embedded; it is a cultural symbol by which the Javanese people, for 
instance, should speak by, for, and within their reflection on that form. The sense of place and time is also embedded in the architectural buildings, including mosques. It means that mosque is a center of place and time for, with, and against which the Javanese people identify.

The definition of architecture leads to reinterpretation of culture itself. The term 'culture' is problematic as it is always transforming to and transformed by many social actors to achieve particular political and ideological ends. It is an invented tradition used and abused by the 'users', often practiced in non-ideological customary and quite religious ways (Hobsbawm, 1983 : 2). This article, furthermore, attempts to unlock such custom definition of culture by figuring out the ideological discourse behind it, because the architecture as an inseparable part of culture has commonly been created with certain ideological basis. In Java, culture is more problematic, because it is interchangeably tied together with political and power relations throughout the history of that island.

Among the conceptual terms above, the more complicated are probably Islam and Java. Even though this study carefully and clearly provides definition of both terms, it remains no fixed definition on them. There is much debatable situation behind the difficulty of getting single definition of Java and Islam. One could find Islam in Java as much as one could find Java in Islam. It represents the ungroundedness of the terms 'Java' and 'Islam', the contestation over the boundary between them, and the question of unresolved conciliation express an undercurrent. Even though I position both terms in an exact analytical way, it is often problematic. For analytical purpose, however, I do this by referring Islam more as the glob$\mathrm{al}$, and Java as the local. The best term of the difficulty to label them is what (Kusno, 2003) uses by "the reality of one-which-is-two", because Islam, like Java, is both local and global at the same time. 


\section{Discussion}

\section{Pre-colonial Java, 1498-1830: A Clash of Demak's} Mihrab

The dispute over Java and Islam in terms of architectural designs firstly occurred in the $15^{\text {th }}$ century when the Java has gotten much influence from the Middle Eastern Islam prior to the Dutch colonial. There was a building of Demak Mosque, the greatest mosque in Java, which marked the first Islamic kingdom in Java after the dominance of Hindu kingdom Majapahit. The cultural clash between Islam and Hindu in the precolonial Javanese people has been well documented in Babad Jaka Tingkir (History of Jaka Tingkir). For the purpose of this study, it is important to use this manuscript since Babad Jaka Tingkir is written as an epic historical report of Islamic power in Java. As many other babads, Babad Jaka Tingkir is anonymous, written for configuring the power of King Demak in the land of Java with many fantasies and prophecies on the rule of Demak kingdom (for detailed discussion on the babad, see (Florida, 1995).

In a part of the chapters in Babad Jaka Tingkir, a story behind the construction of Demak Mosque is recorded based on the first coming of nine saints (Walisongo) to Java. The unknown author of this Babad notes that Demak Mosque is built by using Javanese symbolism in order to integrate Islam into Java. The dialogue between Middle Eastern Islam and Javanese cosmology is also provided in the manuscript, representing a kind of negotiation surrounding Demak Mosque. There is a story behind the building, which inspires the understanding that even in the sacred architecture, the political contestation occurs. The two 'worlds' (Islam and Java) get involved in continuous dialogue before and after finishing the mosque.

The orientation of mosque (kiblah) toward $K a^{\prime} b a h$, spiritual center of Islam, is one of the stories behind the debate over the construction of Demak Mosque. Once the construction of the mosque 
was finished, , the main problem rests: whether or not it should be directed toward $K a^{\prime} b a h$. Surprisingly, the mosque does not face to $K a^{\prime} b a h$, but orients itself to the west (or northwest). It is important to note that even at present time, some modern people have different perspectives on kiblah and west. Going back to the Demak Mosque, it is understandable that the mosque was built as nearly as directing its mihrab toward Ka'bah of Mecca, yet the Babad Jaka Tingkir recorded a complicated story of this. . The babad reveals that Demak Mosque would not face to kiblah; clearly speaking, this incredible mosque built by Moslem people in Java does not orient itself to $K a^{\prime} b a h$ of Mecca, their spiritual center.

The different understanding of this orientation is partly due to the different interpretation of the kiblah itself, which means "to face Mecca" and "to obey" (Kusno, 2003 : 66); (Florida, 1995 : 335). For the architects of Demak Mosque, both terms do not have the same meaning, and consequently the orientation of the mosque did not have to face, but essentially to obey. Following God's commandment, directing the mosque toward Mecca is not obligatory. The clash between two authorities thus took place in and around the building itself:

\author{
But all the Wali eight \\ of vision still did clash \\ The mosque nudged to right and left \\ swinging to and from north to south \\ still never came to rest
}

It is only when the Wali intervened that the mosque put to rest. The author of the Babad indicates that the Wali negotiated with both the Mecca Ka'bah and the Demak Mosque to coordinate axis of power that could bring the two centers together into an alignment, producing what has been known as the double identity:

Allah's Ka'bah did his right hand grasp

His left hand having taken hold

of the uppermost peak of the mosque 


\begin{abstract}
Both of them he pulled
stretched out and brought to meet

The Ka'bah roof and the peak of the mosque

realized as one being were

perfectly straight strictly on mark
\end{abstract}

It is not surprising that Demak Mosque is oriented to northwest, but its mihrab still faces Mecca. For this mosque, kiblah refers to the direction of prayer rather than the building. However, mosques are often invoked to orient its direction toward the $\mathrm{Ka}$ 'bah in Mecca. During prayers, worshippers form long rows facing the Kiblah wall, which often has a mihrab or a niche within that wall to emphasize the direction of Mecca. In today's Indonesia, there are many mosques that are built as parallel as other surrounding buildings, but its mihrab keeps facing Mecca. Entering such a mosque, one will find some degrees of obliqueness (derajat kemiringan) in the shaf (a straight line of prayers) inside it. This obliqueness are commonly under consideration of architectural styles, or the construction of building has not enough space for directing it to $K a{ }^{\prime} b a h$.

The axis of power has been challenged under construction of Demak Mosque, whether it is Ka'bah of Mecca or Eastwest of Java? Or the most importantly, is it purposely built to bring the two centers together into an alignment, producing a cultural intersection of Islam and Java? If it is thoughtlessly understood, it will lead to an assumption that Javanese people during the period of Demak Kingdom are rebels against new faith in Java. However, by recognizing the history of Demak as resulted from the glorious war over Majapahit, it is logical that representation of Hindu-Javanese is still alive in any construction of sacred buildings. More localized the mosque is built, more Javanese values are incorporated, and this fact clearly takes a challenging defense to the new arrival religion of Islam in Java. 

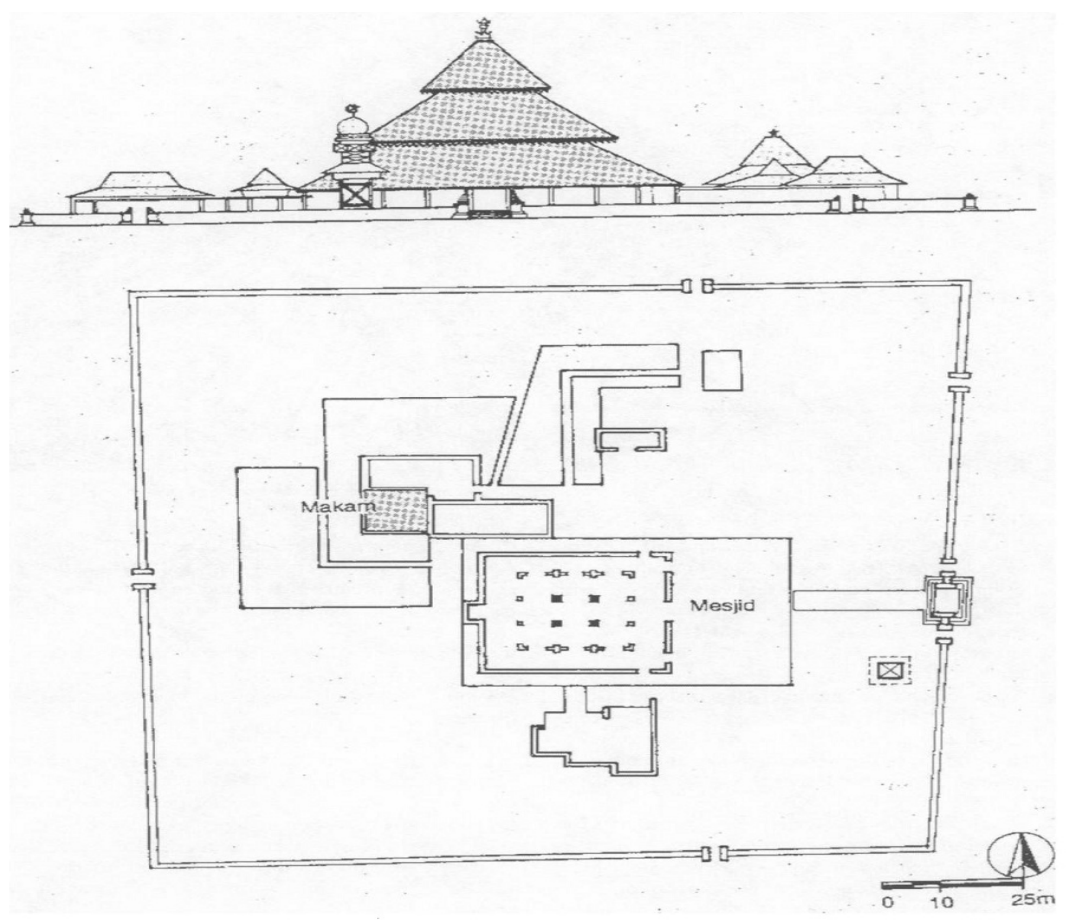

Figure 2: The font elevation and site plan of the Demak Mosque, fifteenth century, Demak, Central Java. Source : (O’Neill, 1993)

The cultural pivot point of Hindu-Javanese has made the global Islam going back to the local landscape of Java. This religion is ultimately approved, modified, and commodified under any aspect of Javanese life, including architectural design of sacred buildings. The Mecca, as the spiritual center of Islam, globally placed in the Saudi Arabia, is regarded $\mathrm{t}$ as center of Islamic direction rather than center of Islamic building. Every single of mosque, especially its mihrab, should be oriented to the center of Mecca even though it is built to other compass points. In Javanese worldview, Islam is localized and incorporated to become an element within the larger cultural framework of Java. This process results in a new insight that Java is part of Islam and vice versa. If the cultural ambiguity occurs in the mid of this interchangeable part of Java and Islam, it is referred to as a strategy rather than threat to have a cultural resilience in the rapid flow of global modernization. 


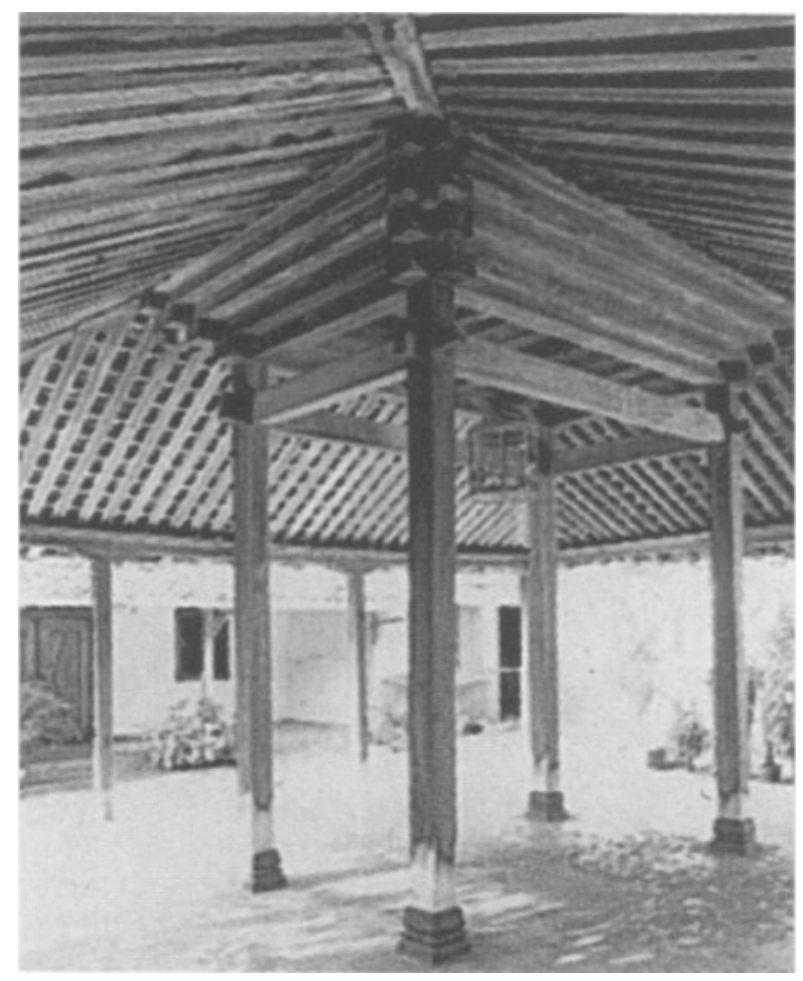

Figures 3: The four master pillars of an ideal Javanese mosque.Source: (Kusno, 2003)

Event though Babad Jaka Tingkir provides a detailed, but almost personally, story of the vulnerable Islam before the Javanese values, it conversely points out that Java is not the center of universe, as gloriously proclaimed under the story of great Majapahit Kingdom. The encounter with "the other" (Islam) has made Java aware of its own limit, and from this point, a new boundary has been made and contested until today. To some extent, this boundary is created through two processes of 'counter-construction' subverting the Javanese social hierarchy in Demak Mosque. The first is that one of the master pillars, the 'grounding authority' of the mosque, was inadvertently built at the very end. The Wali, who is known as the most "Javanese" in character, had to put together a master pillar from the residue of building materials found on the construction site. Until today, this residue is the most sacred object 
of Demak Mosque, and it disturbs the normal hierarchical order of Java (Wolters, 1982 : 33-35). The second counter-construction, and probably the most important, is the peculiar relation between the pillar and the roof. At first look, the four master pillars support the elaborate three-tiered roof structure of the mosque. However, a detailed study of the construction of this mosque reveals that "what we have in this process is the insertion of Islamic egalitarianism into the traditional hierarchy of Javanese polity" (Kusno, 2003 : 66); (Florida, 1995 : 336).

\section{Colonial Java, 1830-1945: Middle Eastern Kubah as European Taste}

However, in the last quarter of the 19th century, with the opening of the Suez Canal in 1879 and Dutch arrival in 1800s, the contact between the Middle East, Java, and European cultures was highly increased. One architectural inheritance, presumed to be originally from the Dutch colonial era, is the introduction of Middle Eastern architecture with its kubah (Islamic dome) of mosques in Indonesia. Kubah in Bahasa Indonesia (from Qubah) is translated as 'Islamic dome'. In 1622 the first mosque was built in the village of Quba, outside Medina. It is known as the Quba Mosque. However, mosques in Indonesia recall the kubah (dome) shape in the Mughal and Indo-Islamic architecture in India. Precedents for the kubah mosques occur in Arabian, Indian (Hindu, Mughal, Rajput), Middle Eastern, Moresque, Moorish (Andalusia), Moroccan, Ottoman, Persian, Russian, and Tunisian architecture. Islamic architecture is used to signify Muslim architecture located in the Islamic world. References are very widely depending on the period in history, the country of origin, and the author's preferences.

The Sukabumi Grand Mosque, which was designed in a Middle Eastern architectural style with two-tiered roofs, was built in 1838 by Tumenggung Raden Surya Natabrata (Figure 4). Mostly known as Masjid Kaum (Community Mosque) because of its place 
near the surrounding residences, the Sukabumi Mosque has been restored twice in 1912 and 1936 . The 1912 restoration figure out that Sukabumi Mosque a square building made of wood with the shape of three-tiered pyramid and a wide hipped meru roofs (without any minarets), a similar shape to Demak Mosque in Kudus (Figure 9). After taking control of the mosque in 1939, the Dutch built a luxurious Moorish mosque with two huge minarets. It is completely different from its previous shape, from a layered pyramid roof to a Middle Eastern kubah (dome) as being symbolic of Europe taste (Figure 5).

However, building mosque had not merely a physical, but also psychological impact on the Dutch, for they had to make it on their own styles. In the case of Sukabumi Mosque in West Java, for instance, after taking control of the fortified Tumenggung palace during period of Java War, the Dutch wanted to start a policy of goodwill, which was symbolized by rebuilding the Great Mosque destroyed in the second expedition. They embodied decorative elements into the mosque associated with the artdeco design of the Middle Eastern style. Thus, the new mosque with the uncommon dome for indigenous mosques at the time was built.

The Java War involving Dutch troops and Javanese armies did not extremely bring a great impact on transformation of mosques. Since Dutch's awareness of the importance of taking sympathy and "spreading European monastery over Java" (Kusno, 2000 : 34), they did not burn the Demak Mosque. Interestingly, the Dutch Indies colonial architectural style through appropriation of kubah could be found in Cut Meutia Mosque in Jakarta. The mosque is named as Cut Nyak Meutia in that she is a national heroine who took part in the battle against Dutch colonialism in Aceh. The mosque was initially built as architectural office, but then transformed into one with modern Indies style. The mosque contains not only ventilation in the tower center of the building, but also a kubah in the top of the roof. Since many aspects of the office building are fitted into 


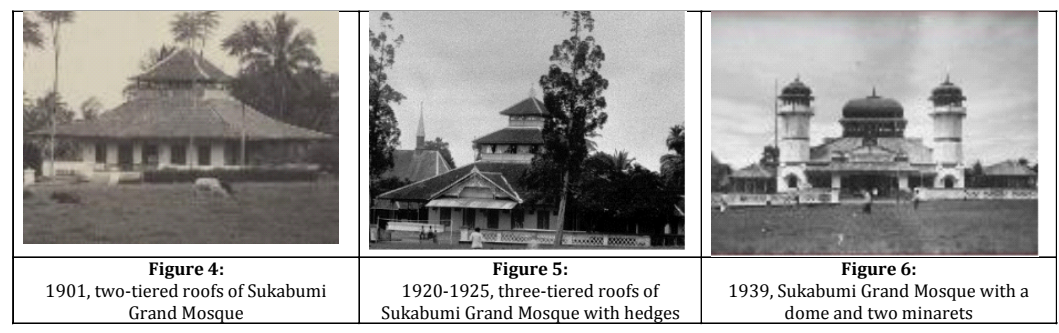

a mosque, the building shows some adaptable layouts, including a fact that the mosque does not orient its direction to the $K a^{\prime} b a h$; the direction of the prayer hall is oriented around 45 degree with mihrab and mimbar in the middle of the hall.

Little attention is given to sources of mosques in Java during colonial period. According to O'Neill, the Dutch architect Hendrik Lucasz, for example, designed a mosque in Java in the $17^{\text {th }}$ century, which included a minaret that resembled European lighthouse and was modeled on contemporary buildings in Holland (O'Neill, 1994 : 235). However, for van Dijk, it is not altogether certain that Lucasz was the architect of the mosque (Dijk, 2007 : 17). During the $19^{\text {th }}$ century, notes on the Indisch-European architecture were commonly based on works of Maclaine Pont and Thomas Karsten with academic, cultural, or office building heritages, such as Building Techniche Hogeschool Bandung (ITB - Pont, 1919), Theatre Sobokarti Semarang (Karsten, 1930), Sonobudoyo Yogyakarta (Karsten, 1930), Church Pohsarang Kediri (Pont, 1936), etc. These Indo European architectural styles are classified as seeking a synthesis between European construction systems and oriental art form (Handinoto, 1996 : 23); (Jessup, 1985). However, in the later discussion, I will show that double identity between modernist and traditional, between Javanese and Islamic architectural visions, is obvious in those buildings, including ITB.

Given the fact that mosque is one of many architectural buildings during colonial period, it is also true for other buildings. Modernity during the Dutch rule came into its peak in the 1930 s 


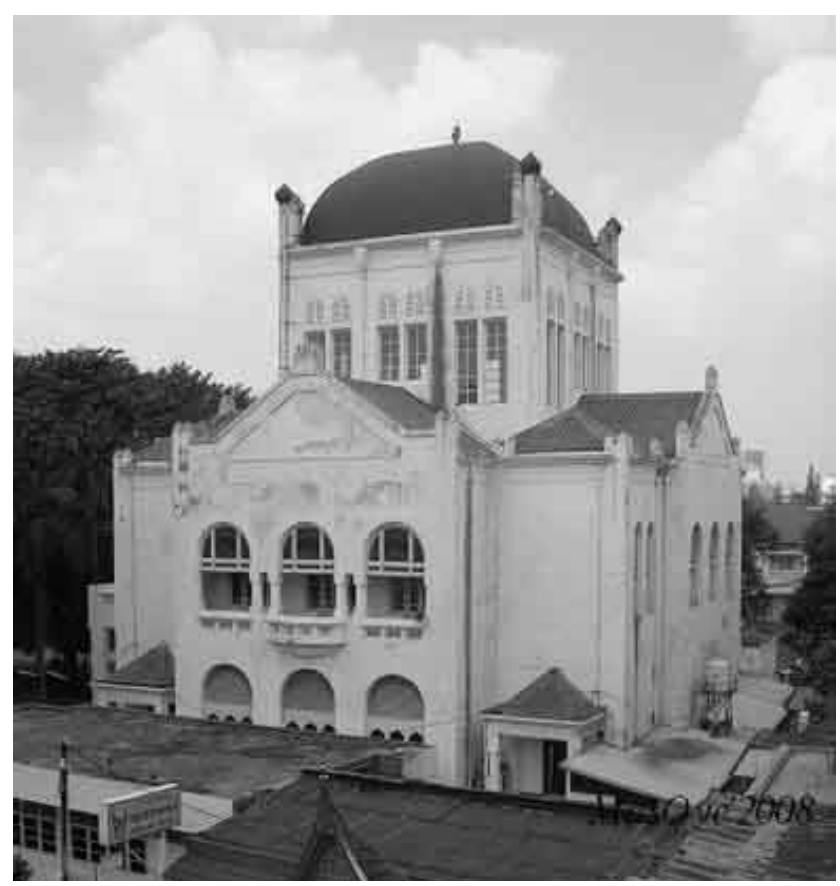

Figure 7: The ex-Dutch office building of Cut Meutia Mosque at Jakarta in the $20^{\text {th }}$ century with 'Islamic' dome (Source: National Geographic)

when the urban landscape was transformed and embellished with more and more European style buildings in various styles: Imperial, Victorian, Palladian, Moorish, de-Still, Art Deco, Edwardian, and Dutch local hybrid (Wiryomantoro 2012, 208). Representing a European city in the colonial land reflects the romantic need for home in a foreign and lonely land. For example, Bandung is well known as "Paris van Java" and Batavia "Amsterdam of Java." Moreover, in the field of urban design, the Dutch Colonial Rule established and elaborated towns and cities in Java with an attempt to adopt a traditional structure and layout (Akihary, 1990 : 35-85).

To demonstrate their power, the Dutch installed a highwalled prison at the corner or close to the square, alun-alun. The purpose of adopting a traditional structure and layout was to minimize conflicts with local rulers. Accordingly, the seat of authority from district to regency has always provided the traditional square 
of alun-alun with many trees as its urban land mark. The seat of authority called Dalem (which literally means "inner" or "core") has always been equipped with an open reception hall known as a pendapa (Wiryomantoro 2012, 207). In alun-alun, the Dutch usually built a Masjid Jami' (Great Mosque) in order to indirectly control the economic, political, and religious life at large. Symbolically and architecturally, the Dutch presence watched over the local ruler, religious followers, from a close visual distance. In the Javanese traditional capitals of Yogyakarta, Surakarta, Surabaya, Semarang, and Jakarta, Masjid Jami' is easily found in the mid of their alun-alun. In the center of the urban design, location of Great Mosque in alun-alun represents the ways the Dutch viewed Islam in a similar way as Roman Catholicism, with a hierarchical clergy that owed allegiance to the Turkish Caliph who, so the Dutch thought, had great influence over Indonesian Muslim (Maussen, 2009 : 92). The Dutch sought to create alliances with these elements in Indonesian Muslims: the priyayi who constituted first and foremost an aristocratic civilization of their own; the santri who developed civilization around the religious leaders; the ulama who had become counsellors, judges, and religious teachers and began to have increasing impact on the religious, social, and political life of Indonesia (Benda, 1958 : 19); (Steenbrink, 1993).

\section{Post-colonial Java, 1945-1965: Soekarno's 'Modernity'} Vision

Architectural development as an integrated part of development was not well addressed in Indonesian history before the birth of the Republic of Indonesia in 1945 (Wiryomartono 2012, 210 ). Prior to 1960s, the new Republic was still struggling to maintain its politically and economically stable government. Unlike the Dutch Colonial Rule that exercised urban policy of apartheid, the first President of the new Republic established his authoritarian 
regime with Javanese guided democracy. He was a leader of a new nation with an aesthetically new Indonesia (Legge, 2003 : 56).

Rhetorically inspired by the glory and grandeur of the Javanese Majapahit and Sumatran Sriwijaya kingdom, Soekarno insisted that the country needed him as a revolutionary and visionary leader. However, ideologically and technically, development did not work well until the Presidential Decree in 1959. The government was unable to carry on any long-term programs due to political instability (Feith, 1958 ; 25-39). Since the decree, which was supported by the Armed Forces, Navy, Air Force, and Police, as well as by his own Party (Nationalists Party of Indonesia), development became unifying credo for newly emerging nations liberated from colonialism and imperialism.

Soekarno's architectural vision is, to all appearances, a modernist one, founded in a vision of freeing Indonesia from the shackles of colonialism, looking forward to a future in an international arena of modern nations rather than getting back to its traditional past. This vision is articulated in a series of large monuments, roads, and skyscrapers in the capital city Jakarta. For the first time, Indonesia under Soekarno's regime initiated an agenda for hosting the Asian Games in 1962 (Hong, 2006 : 12). The grand plan of Soekarno for the modern national capital Jakarta was done in the 1960s as the Lighthouse Project or Proyek Mercusuar, which was identical with a flamboyant and megalomaniac project (Gugler, 2004 : 271) It was then followed by other megaprojects, such as high-class Ambarukmo Hotel, Senayan Venue Complex, Taman Merdeka (Freedom Square), and Tugu Monas (National Monument). The last project was resulted from an embodiment of sacred phallus in the Javanese idea of power, which is concrete and cosmic mystical, homogeneous in source, constant in quantity and no legitimacy required (Anderson, Benedic, and O'Gorman, 1997 : 5-7). 


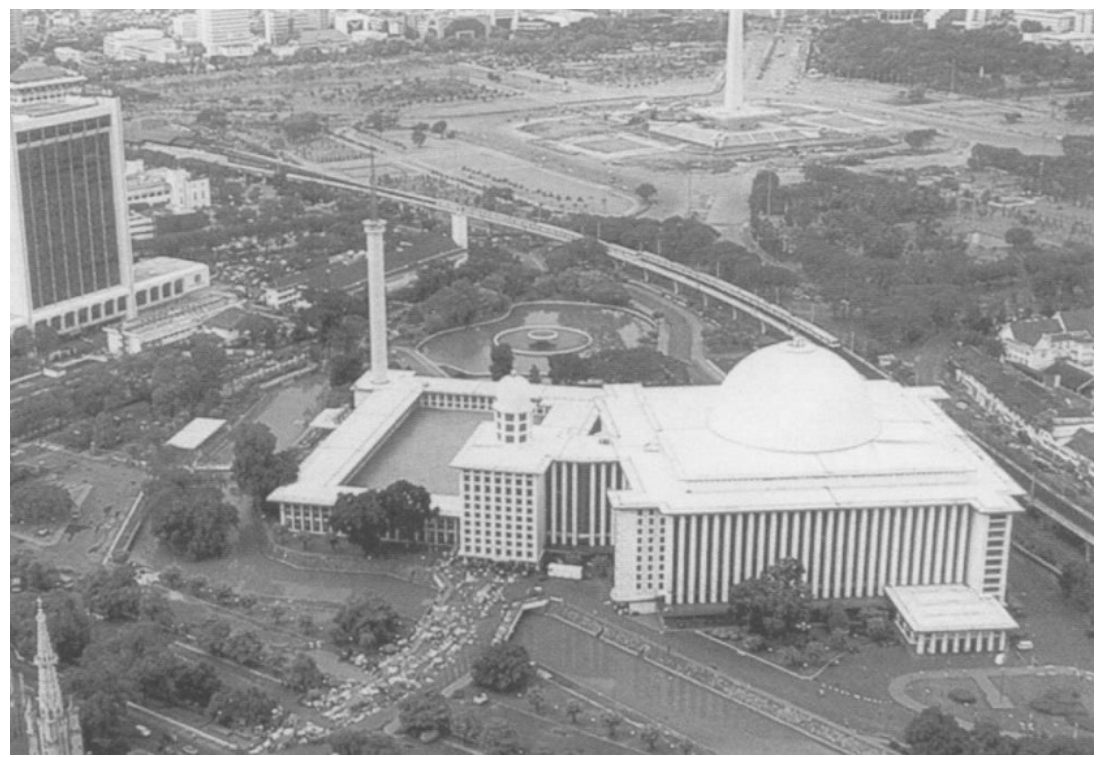

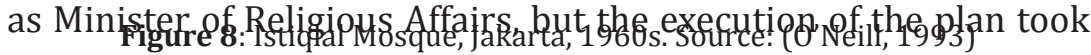
almost a decade. Soekarno laid the first stone of the foundation in 1961. The mosque was actually completed in 1978 and opened publicly for the first time by Soeharto. From a limited design competition, he finally picked a design of the mosque. The Protestant Frederich Silaban was the main architect and his design incorporated modern structural material with a 45-m diameter dome and a simple rectangular plan of $100 \times 100$ meters. The most interesting part of the mosque is the design of its wall system, consisting of rows of columns, which are adaptive to a tropical climate. The ambience of daylight coming through the gap between the exterior wall columns creates a magnificent interior space.

Architecturally speaking, the mosque is modern with great kubah (Islamic dome) in the top of the roof; it was built with a simple geometric form and an urban scale proportion. In addition to having European taste of Middle Eastern kubah, the idea of modernity has been incorporated in the use of materials and a functional operation for more than 100,000 prayers at a time. It is the gigantic 
mosque of the highest population of Muslims in the world as the never-forgotten symbolic idea of Soekarno's vision of Indonesia as a great country.

In his great oration, Soekarno said, "What! Would we build a Friday Mosque like the Masjid Demak, or Masjid Banten. I'm sorry! When it was built it was already great. But if erected today what would it rank, technical colleagues? ... I have seen the great mosque of Istanbul... I have seen the mosque at Lahore... I have seen the great mosque at Old Delhi ... they are beautiful. But, in my mind, Indonesia will build a mosque that is greater than all these.... greater than the Mohammad Ali Mosque in Cairo. Why? We have a great nation! We are always amazed!" (Soekarno, 1990 : 242)

What Soekarno implies with the greatest mosque is Istiqlal, mostly known as the greatest mosque in Southeast Asia. He argues that Indonesian architecture of mosque could be negotiated with Middle Eastern, even European's architectural style. Soekarno has successfully articulated the significance of the power of politics (through his position as President at the time) in the mid of global negotiation of architecture, culture, and religion. His political oration is ideologically architectural, or conversely his architectural idea is ideologically political. The internationalist style of Istiqlal Mosque, built in Java, provides a new challenge of idea of what Indonesian mosque architecture should be during the pre-Reformasi period.

The modernist architectural form of Soekarno's vision has been well documented (Anderson, 2006 : 173-174); (Nas, 1993); (Leclerc 1997); (Macdonald, 1995); (Dovey, Kim, 2010), but appearances can be misleading. A recent study (Kusno, 2000 : 68) notes insightfully that while the architectural image (of modernism) may be constant, its 'denoted meanings' may vary according to local contexts, meanings, and intentions. Behind Soekarno's modernist aesthetic, as Kusno argues, was an attempt to establish a symbolic center of power, founded less in the supposed rationalities of mod- 
ernist planning than in ancient Javanese (originally Indic) notions of the expression of cosmic sources of political power in spatial and architectural forms (Kusno, $2000: 60-62$ ).

Fifteen years after the establishment of the Istiqlal Mosque or five centuries after the establishment of the Demak Mosque, in 1970, a well-known Javanese architect Mintobudoyo designed and built in central Java (in the Taman Sari Royal Garden complex) a small mosque for the Javanese royal family. This column branches out into four "Javanese master pillars" supporting four corner beams of the upper roof. It seems that the intention of this architect was to construct a focus, a vertical center that represents the "unity" of the Javanese and the Islamic world. The vertical column pays tribute to the global Islam, and the horizontal spread of the four Javanese mater pillars confirms the existence of the local power.

Mintobudoyo's architectural vision is, certainly, based on Javanese values. This architect is well known as one who would rather resign and give up the job than allow his mosque to be directed toward the kiblah (Saliya, Yuswadi, Hariadi, 1990). It is popular among Indonesian architects, "to him (Mintobudoyo), a Javanese mosque should face East, any deviation from this direction for a mosque would violate the Javanese rule." The commissioner accepted his vision by building the mosque as he wants to be directed. However, it is not clear whether or not Mintobudoyo consulted his visionary architectural design with other architects, because the inner design of the mosque is inspired from the similar idea of the Demak Mosque. It is likely to say that global Islam needs to be localized, and only by so doing, the Javanese values will be under domination.

The centrality of global Islam and local Java is best illustrated in terms of how the form of architecture needs to hide its content and ideological vision. The boundaries between Taman Sari small mosque and great Istiqlal mosque are y blurred during Soekarno's Javanese Guided Democracy system. 


\section{Post-colonial Java, 1965-1998: Soeharto's 'Traditional'}

\section{Conservation}

Soekarno was in the end never able to complete his monuments, let alone reconcile this philosophical double identity, but he was ironically undone by other more mundane political-economic contradictions in 1965. A regime that came to be known as the New Order, headed by General Soeharto, took over in dramatic and bloody circumstances in 1965-1966 and remained in power until 1998. It was highly centralized, authoritarian, military-backed regime that never hesitated to use force to control its people; but its preferred method of control was an ideology of national unity, political stability and development inculcated through the administrative and education systems. Soeharto's architectural vision was subsumed into the service of this ideology, mostly in the form of politically sanitized styles and performances, in which any traces of local, let alone ethnic, art worlds were reduced to superficial tokens of 'cultural diversity', surface decoration covering any crack in the façade of political unity (Acciaoli, 1985); (Pemberton, 1994).

The architecture world of the New Order was consistent with this model. On one hand, the opening of the country to foreign investment and the emphasis on economic development led to a proliferation of (mostly mediocre) copies of mainstream modernist construction, especially commercial building in the urban centers. On the other, it introduced and celebrated tokenistic representations of 'traditional' styles. The apogee of this was the much-documented 'Beautiful Indonesia in Miniature' theme park (Taman Mini) in Jakarta (Anderson, 2006 : 176-177); (Errington, 1998 : 194-199); (Pemberton, 1994); (Hitchcock, 1997); (Kusno, 2000 : 74-78). This double identity between modernist practice and traditionalist decoration was rarely recognized, let alone consciously articulated or bridged.

However, Kusno discusses two exceptions, both on campuses of major state universities in which issues of national identity were 
paramount, i.e. Bandung Institute of Technology (ITB) and University of Indonesia (UI) (Kusno, 2000). When ITB was extended, largely to accommodate new scientific and technology facilities in the early 1990s, there was a need to find some accommodation between the new buildings and the old ones. The solution chosen was to divide the campus into three zones: the original one, now designated 'konservasi-historis', and a 'transisi' zone that links the two. Kusno views it as architectural as well nomenclatural, as simply an erasure of the realities of national history. Ironically, though, its colonial/Indonesianist origins are always embedded in the overall site plan (Kusno, 2000 : 81-85). At around the same time, when UI began building a new campus on the southern fringe of Jakarta, the need for expression of national identity was even more explicit. In this case, the chosen solution was to incorporate planning principles of Indo-Javanese cosmic centrism and of the Javanese pendopo pavilion, Balinese ideas of tripartite hierarchy and tiered roofs, as well as generically archipelagic pavilion/roof forms all superimposed on more or less conventional modernist buildings. Pendopo is a fundamental element of Javanese architecture; a large pavilion-like structure built on columns. Either square or rectangular in plan, it is open on all sides and provides shelter from the sun and rain, but allows breeze and indirect light. In the Joglo house (which is owned by people who have respected social status in Java), pendopo usually became a meeting room or living room, a space that is used to hold a shadow puppet show. Unlike that of the zona-transisi at ITB, UI uses different logic with repetition of the Dutch invention of tradition than an accommodation to the visible traces of colonial history (Kusno, 2000 : 86-88).

The dispute over the double identity also occurred in 1980s, when an Islamic organization was protesting against a research report on Demak Mosque. A group of architects involved in that research shocked the Islamic organization with a finding that Demak Mosque was built on the basis of Javanese monuments. They also provided a quick response to the Islamic organization that their 
focus was on the architectural form of the mosque. The formal stylistic analysis has nothing to do with ritual, practice, and history surrounding it. The journalist who reported the research also warmed the debate by figuring out that the coming of Islam to Java was mostly under influence of Javanese people through nine saints (Walisongo), including Sunan Kudus in Demak, with their high contributions to Islamic preaching through Javanese practices, values, and norms (Luqman, 1986). This leads to an assumption that the spread of Islam in central Java was carried out through local Hindu Javanese, who had inhabited it long before Islam came. Hence, it is logical that Demak Mosque was built partly through inspiration from Hindu Javanese building.

In 1988, the contesting idea of double identity between Java and Islam in architectural form occurred in Jakarta. Rector of a university in Jakarta, M. Sutan Takdir Alisyahbana, proposed the design of the university's mosque on the basis of ancient Hindu

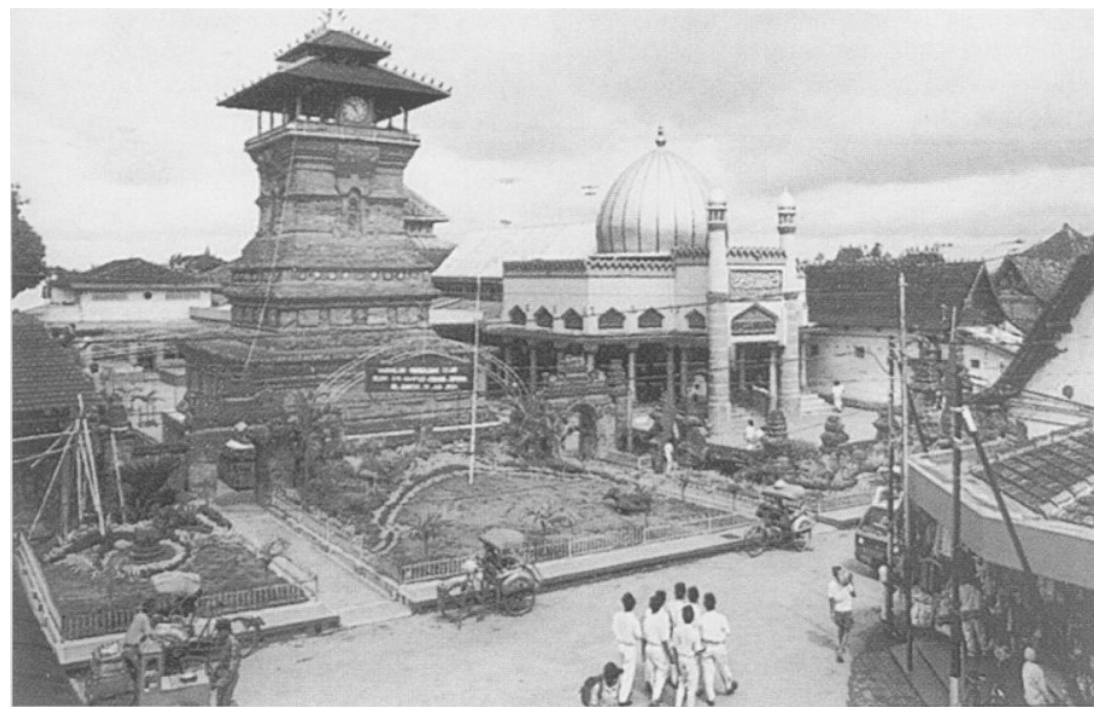

Figure 9: The pre-Islamic brick temple and tiered roof of Kudus Tower, seventeenth century, Kudus, Central Java Source: (O’Neil 1998) 
Javanese monument in central Java. The proposal was delivered in order to honor the expression of indigenous heritage of archipelago. By having three-tiered roofs, the mosque was regarded as promoting original Indonesian architecture, the oldest architecture of Hindu Java. However, the process of the mosque building was not easy. The rector circle was involved in a long debate on whether the mosque is a symbolic building of Islam or non-Islam. "I don't feel comfortable with the form, because I don't provide you with a sense of mosque. Maybe I am conventional and Mr. Alisyahbana (the rector) has a creative idea. However, there is no Islamic character in the building," a staff of the university said. After a long debate over the building, after the intimidation that funding institution was not happy with it, and after high pressure over rector's proposal of the mosque, M. Takdir Alisyahbana finally accepted, albeit reluctantly, their ideas to change the 'Hindu' mosque into the 'Islamic' mosque which included a tiny pan-Islamic dome on the top of a three-tiered Javanese roof (Cholid, Mohamad, 1988). The proportion of the monumental Hindu-Javanese was also highly reduced from the mosque.

The escalating conflict surrounding the debate over what Islamic mosque should be in the history of Java has been increasing for years. This unending tension is actually based on the ambiguity of post-colonial idea on the double identity of Java and Islam. Java, an island with the history of double genealogy of Hindu-Majapahit, Islamic-Demak, and Syncretic-Mataram, is a place in which the understanding of architecture is still debatable and unfinished (Fawaid, 2015). In terms of many religious organizations in Java, any proposal related to sacred building is inseparable from silent ideology behind it, between the Hindu-Javanese proponents on the one hand and pan-Islamic proponents on the other, between Javanese traditionalists on the one hand and Islamic traditionalist on the other, between pluralism of Hindu-Javanese culture on the one hand and monotheism of Islam on the other, and other terms. The fact that building sacred mosque is always tied together with 
an ideology of whom has built it has produced a kind of cultural, religious, even political negotiation among them. It figures out that sacred mosque and its silent ideology has always been contested, modified, and negotiated in the history of Javanese and Islamic architecture. The problem is whether this debate leads to the bigger issues related to global-local identity of "one-which-is-two" itself?
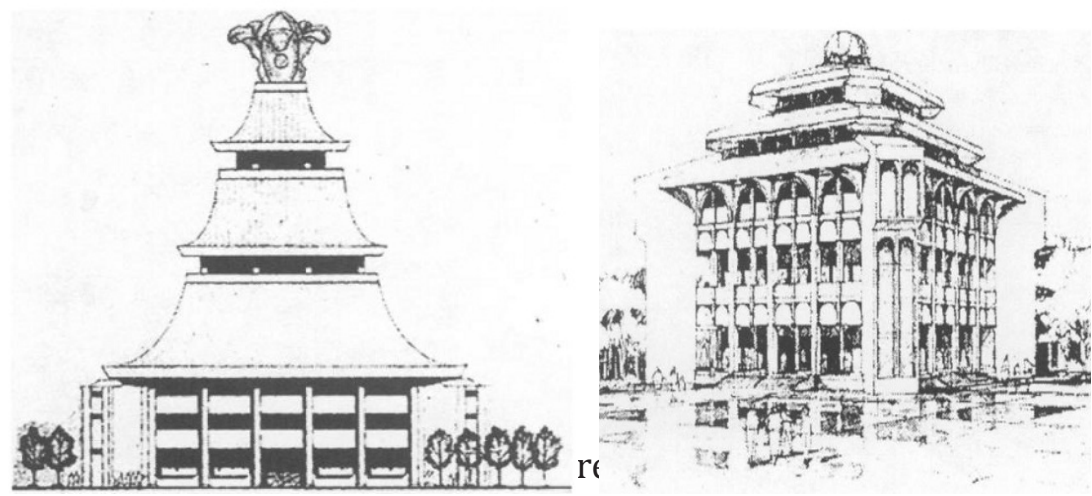

tional mosque in Pamekasan Madura, namely At-Taqwa Mosque, Figure 10: The first design of Universitas Figure 11: The revised version of whisian construction, having three-tiered roofs and orienting to northwest rather than Ka'bah. The At-Taqwa is a formal, standardized replica of Demak Mosque, which still remains a powerful force in Indonesian governance. The story behind the building of At-Taqwa is actually resulted from the political will of the ex-President Soeharto (1966-1998) who mandated a restoration and renovation of Demak Mosque in 1987 as the nation's spiritual capital. "Demak mosque is the only heritage and should not disappear from Java," reported one of the journalists at that time (Kompas 1987). Soeharto, who was culturally known as King of Java, had special interest in preserving the Demak Mosque, and by his political power, the mosque 
became one of ultimate models of sacred national heritage. In every province in Indonesia, many mosques, including my grandfather's one, reproduced, rearticulated, and remade up the design of Demak Mosque, successfully demarcating and crossing borders over time and place in Javanese society.

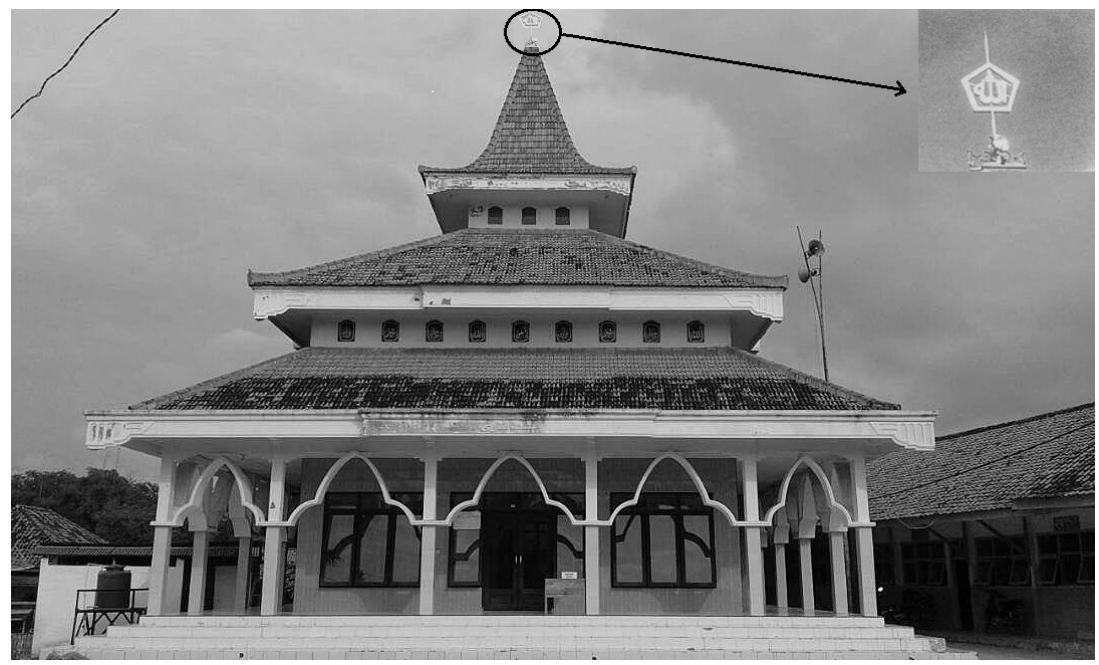

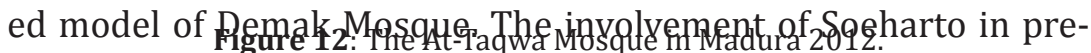

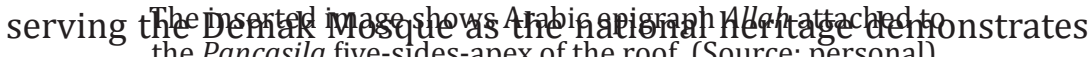
the Pancasila five-sides-apex of the roof. (Source: personal).

that architecture of sacred mosques is not a blank space; it is always negotiable in the continuous dialogue with culture (Java), religion (Islam), and-now-politics (Soeharto). The negotiation between the realm of Islam and the domain of Java is mostly explicitly shown in the lightning conductor installed at the apex of the roof. Attached to this antenna is a hollow pentagonal frame, which encloses the Arabic epigraph for Allah. This pentagonal frame is known as representing the five principles of Indonesian nationhood, Pancasila, a Sanskrit word indicating the embodiment of Hindu-Javanese culture in the nation-state. 
The double identity of Islam and Java reoccurred in the apex of pentagonal frame of the mosque. Even though the apex is only labeled by Arabic epigram Allah without pentagonal frontiers (as many modern dome today), but the three-tiered roofs in the mosque has clearly gotten its inspiration from the Demak Mosque resulted from an interaction between Islam and pre-Islamic architectural tradition (Javanese culture). Finally, through Soeharto's political will, this interaction has entered to the national standard, pointing out that double identity of Islam and Java is almost impossible to be created without emergence of the powers of politics constituting the remarkable ambiguity of the architecture vis-à-vis political policy (O’Neill, 1993 : 157-158).

\section{Post-colonial Java, 1998-2017: Mosques after Soehar- to's Fall}

The new order regime ended in May 1998, as abruptly as it began. Less blood and fewer tears were shed than in 1965, but the ensuing economic crisis and political turmoil is only now, almost two decades later, beginning to settle. This has been a period of reformasi (reform) of political and administrative orders, but also one in which Indonesians have had to reimagine and rebuild their nation in terms of identity and culture as well as political and economic order. One key aspect of reformasi has been desentralisasi (decentralization), a devolution of budgets, decision-making and democratic process to lower, more local levels of administration. However, the level to which official autonomy has been devolved has been the district (kabupaten) rather than the province. Ethnic identities tend to correspond more to the provincial level, so this arrangement has tended to internally divide rather than reinforce local ethnic identities (Buehler, 2007 : 119).

Despite the fact that it was almost two decades after the fall of Soeharto's New Order regime, architecture and urban design 
in the country did not show a significant change but was the same business as usual. The majority of architects are unashamedly in the business of business (MacRae, 2011 : 104). Restoration and rebuilding of buildings, which were burned down in 1998 riots, were the main activities of development after the fall of Soeharto's power. Contemporary architecture in Indonesia is dominated by what might be described as a global/modernist paradigm in economic, aesthetic, and philosophical term (Wiryomartono, 2012 : 218). Modernity was interpreted as the reformation of civil society, but the problem remained the same.

More affluent metropolitan centers of Indonesia have sprouted concentric rings of commercial buildings, shopping malls, housing estates, and toll roads. However, traces of 'traditional' styles are visible in these kinds of buildings only in occasional token displays of applied ornament. Less affluent areas are sprawling masses of smaller, cheaper, shoddier, and even less-designed versions of the same range of forms, but usually spared the presence of 'traditional' decoration. However, the forms of traditional building have virtually disappeared except in two areas. One is the everyday architecture of the poorest and most rural people, who continue to build rudimentary shelters using much the same methods and the same materials that have been used for centuries. This practice is driven by expedience rather than any sense of tradition. The other is in certain parts of the country where more conscious notion of local identity and traditional culture are strong, for example in Bali. The sense of distinctive Hindu culture is very strong, but it is often related to and financed by global tourism (Reid, 2002 : 90); (Waterson, 1997 : 234-242). These are best understood in terms of reaction rather than engagement with modernizing, globalizing, or nationalizing forces.

It also shows that global and local architectural styles are more and more blurred during post-Soeharto era, and this mixture gets more increased level with the emergence of racial and religious tensions in various forms and occasions. Most recently, the dispute 
over religious building emerged in Jokowi's initiative to build Daan Mogot Grand Mosque in West Jakarta. Three days prior to the Jakarta gubernatorial election runoff, on April 16 ${ }^{\text {th }}, 2017$, Joko "Jokowi" Widodo and Jakarta Governor Basuki "Ahok" Tjahaja Purnama inaugurated Daan Mogot Grand Mosque, the first city-owned grand mosque named after Hasyim Asy'ari Grand Mosque (Masjid Raya Hasyim Asy'ari), a renowned ulama who founded Nahdlatul Ulama (NU), the country's largest Muslim organization.

The Hasyim Asy'ari Grand Mosque was built as a positive symbol of moderate Islam. In the inauguration of the mosque, Jokowi delivered a speech (The JakartaPost 21/4/2017), which reminded us to Soekarno's speech in celebration of Istiqlal Mosque,

"I have seen Istiqlal Mosque in Central Jakarta. I have seen Al-Azhar Mosque in South Jakarta. I have seen Islamic Centre in North Jakarta. I have seen At-Tien Mosque in East Jakarta. Now, I will see a grand mosque in West Jakarta.... Indonesia is a country that is plural and has diversity. This mosque should become a symbol of Islam that is friendly, moderate, and acknowledges diversity in Jakarta in particular and Indonesia in general. As an ulama [Islamic scholar], the founder of NU [Hasyim Asy'ari] laid the foundation of friendly religious life in the country."

The architect, Adhi Moersid, insisted that the mosque got inspiration from the Nabawi Mosque in Medina, planned to be not merely a place of worship, but also of agricultural, social, and administrative activities. Adapted from bapang house of Betawi, the mosque was built with gable triangle roof and grasshopper teeth (gigi balang) ornaments. Bapang or mostly called Kebaya house is Betawi traditional house with large terrace in which there are living room and bale divan-like structure commonly used for relaxation. Betawi Bapang is like Joglo in Yogyakarta and Surakarta. There is a big triangle in the center, and four small triangles in the front of mosque. Having capacity to accommodate 13,000 prayers, the mosque is also based on five minarets as a symbol of five fundamental pillars in Islam. It is the first grand mosque, according to 
the architect, which laid an urban agriculture as its basic ground breaking, so that people can cultivate any kind of plants around the mosque (Rudi, $2017: 2$ ).

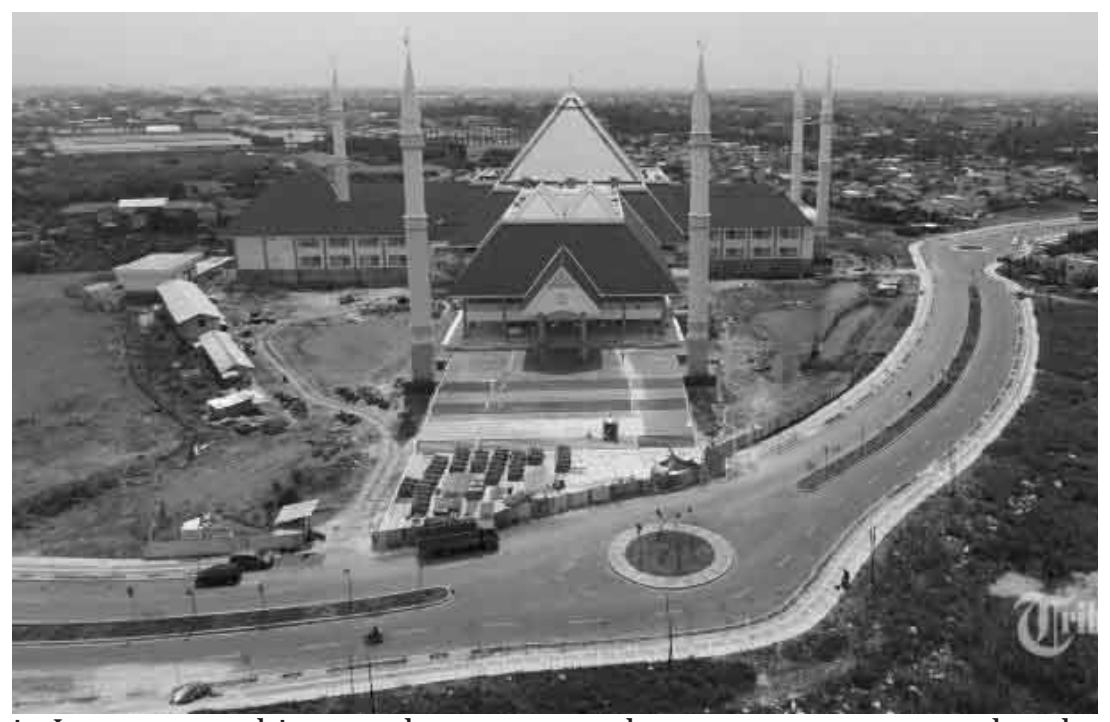

ic-Javanese architectural ornaments does not guarantee the abFigpre 13: The Daan Mggot or Hasyim Asy'ari Mosque, Jakarta, 2017.

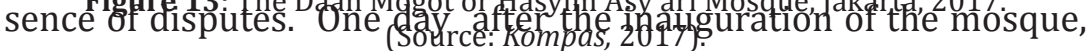
the Indonesian Ulama Council (MUI) accused the President of "promoting secularism" due to his comments regarding the need to separate politics and religion during the inauguration of an Islamic site in North Sumatra. Additionally, M. Din Syamsuddin, a head of Broad of Consideration MUI and a head of the country's second largest Muslim organization Muhammadiyah, stated, "[The President] needs to clarify whether the grand plan of Daan Mogot takes a form of another religion's symbol. If it is true [using another religion's symbols], the mosque will be dhirar, dangerous, so it has to be moved away" (The JakartaPost 15/4/2017).

Seen from the top, the mosque is perceived as having a 
symbol of cross (salib) in Christian tradition. An inspectorate of public policy from the Budgeting Metropolitan Watch (BMW), Amir Amzah, also viewed that the Daan Mogot Mosque had deviated from the District Rule (Perda) No. 2/2012, consisting of regulation on incorporation of Betawi cultural values into every religious building. "... the Hasyim Asy'ari Grand Mosque is deviant (from Islamic tradition). From the top, the mosque is like cross," said Amir (Amir Hamzah, 2017).

In a response to this disquiet, the architects involved in the building of the mosque quickly explained that the existence of 'cross' in the mosque was misleading. "No, nothing [on cross]; that is hoax. I just pray for those who misinterpreted it. May God give them a mercy," said Adhi. Moreover, Sholahuddin Wahid, a grandchild of Hasyim Asy'ari, also made a clarification that it had nothing to do with cross or another religious symbol, but letter " $\mathrm{T}$ " in the building of the mosque. Until today, the mosque is still debatable in terms of its architectural style.

Behind this dispute over Daan Mogot does lay a long disquieted history of Islam in Java, history of Demak Mosque and Istiqlal Mosque, which was composed of an unending tension and reconciliation of the reality of double identity. Questions concerning mixed values between Hindu-Javanese culture and Middle Eastern Islam became greater in the case of Daan Mogot Mosque during the most recent regime of Indonesia. Most critical of all, the increasing sense on the part of a certain Islamic community in Java that un-Islamic components have long been, or will be always, part of Islam, are all caught up in a dispute over the globality, identity, and authenticity of Islam in Java, a contestation over the double identity through the battles of various mosques.

\section{Nation-State: Contesting 'Indonesia Architecture'?}

During almost the whole history of Indonesia, a relation between architecture, culture, and power inclined to address a political agency in the process of mosque building. Nine saints, Dutch govern- 
ment, Soekarno, Soeharto, until Jokowi regimes attempted to havein Anderson's terminology (1996) —an 'imagined community', each in its own perspectives, to localize or globalize it in Indonesia. Nine saints were involved in absorbing Javanese and Islamic values into Islamic building of Demak in a long classic debate, while the Dutch used an authority to carry out the colonial policy to administratively control religious buildings in Indonesia. Soekarno probably envisioned his architectural design of the Istiqlal as modern/international one to be absorbed in many local Indonesian areas, while Soeharto provided his architectural vision of traditional design by representing the Demak as local one to be acknowledged in an international level. During post-Soeharto, architecture of sacred buildings became more and more imaginary a status and symbol of consolidation and reaffirmation of national integrity based on democratic principles.

These agencies are symbols of authority with different political ends of using architecture, and consequently it leads to other important questions on how nation-state should be represented in the architectural form of mosques? Which one of Istiqlal, Demak, or Daan Mogot will be the best national discourse of the religious building in Indonesia? Which one of them will be the competitive in the mid of negotiation between Islam and Java? How do they negotiate their religious cultures with the idea of the secular nation-state? How do Istiqlal, Demak, amd Dan Moogot become part of Islamic and Javanese worldviews? Could the perspective of Islam as part of Java and of Java as part of Islam within such mosques be the starting point of understanding this unresolved dispute over the primordial understanding of nation-state?

These questions are important guides to deeply understand the relation between architecture, culture, and power prior to understanding the idea of nation-state. The modification of this syncretism, for instance, could be seen in the belief among Indonesian architects that the principle of modern architecture, whether originating in the East or West, is at the bottom of the idea of tradi- 
tional Javanese building culture. These two national mosques, each in its own style, are not just an indexical statement that "Indonesia is an Islamic country", but quite the contrary: a mosque shows that Islam has been absorbed, rearticulated, modified, incorporated, and reproduced into the world of Javanese, the world of Indonesia. Crossing the borderlines of this perspective is political intervention during the process of Javanese and Islamic embodiment into the mosques. The new enterprise of national architectures of the mosque demonstrates the political power in creation of religio-cultural faith within the nation-state. However, using secular 'political' framework of analysis, the substantial ideas will be often missing in the architectural discussion. The religio-cultural mentalities in today's mosques in Indonesia demonstrate that there are always other ways to understand nationalism without having focused merely on political perspectives.

The architecture goes beyond a mere psychological issue. The building of sacred mosque which is based on Hindu-Javanese style, Moorish-Middle Eastern style, or Betawi style, with its contestation among the proponents and the opponents of that idea, shows that the architecture is always manifested on the basis of inner and outer expression. Some today's architects assume that stylistic mixture of inner traditional concept and outer modern expression would be the best win-win-solution of getting rid of the long dispute. However, architecture is not just a conceptual design with none of ideological underpinning; it is notably to recognize that every single idea of architectural design will, perhaps, quite often deal with controversial debate among those who use or misuse it for their certain ends. There are always continuity and discontinuity in architectural form, and that is the reason why the architecture is not only physical.

Today's continuum search for totality, such as Arsitektur Nusantara, Arsitektur Indonesia, Arsitektur Pancasila, Arsitektur Tropis, etc. points out that architecture is not a final product in terms of stylistic design; it is always changing over the transform- 
ing situation of culture, politics, even religion at a certain time and place. Today, such ideas of totality gain their relevance among architects in Indonesia, representing that the current idea of-what we probably often termed as- "nation-state" and/or "nationalism" has been challenged for many years. The long debate over what Indonesian, Islamic, and Javanese architectural form should be in the certain place often occur, and it is under main consideration by the architects, leading to an assumption that architecture is possible to challenge today's understanding of nationalism.

If the nation-state is considered pinnacle of local cultures, a simple question will be: How could nationalism be regarded as the global one? The project of nationalism in Indonesia, for instance, is mainly a product of national stakeholders' contribution to the promotion of 'unity in diversity' or mostly known as Bhinneka Tunggal Ika at international level. The bhinneka (diversity) includes not merely ethnicity, but also religion. The tunggal (unity) is a symbolic aspect of Indonesia itself, which covers the different ethnics and religions. However, the $I k a$, which is also delivered from Javanese term, meaning 'a peaceful way of life', is a way that is difficult to reach in today's debate just over the architectural design. In the case of Demak Mosque and a mosque of National University, the concept of $i k a$ is not as easy as we articulate it, for both buildings were built surrounding the users and-most importantly-political players. This figures out the further inference of the architecture in inseparable relation with politics itself.

The power of the hidden concept to cover different architectural expressions is a power of politics. Realizing e that this assumption is, again, problematic because architecture and political power could not be roughly related to each other, I need to remain logical in terms of cultural faith vis-à-vis power of politics in the current situation of the sacred mosques in Java. Since 1980s, according to Kusno, a continuous contestation on architecture and identity has been more than just a sign of professional insecurity in 
the age of free market globalization (Kusno, 2003 : 63). Yet, I note that such a debate took place in the fifteenth century or before; surely, it is also a symbolic war of enormous efforts to protect inner or outer concept of architecture to defend a kind of cultural and religious faith. The confrontation between proponents and opponents of Hindu-Javanese design of mosques represents a political negotiation between cultural and religious followers. This is why many Indonesian architects may not seem to focus much attention on the ideology or politics of architecture. It is not they think a part of 'architectural business.'

Some architects have readily concerned with politics and power, but for some who have recognized that there are some intrigue relations between both of them, the architecture embodies some values that could always overcome the politics itself. I have to mention these groups as 'post-architects', who attempt to have a architectural design overcoming any other different ideas, including politics. They are also aware of the inseparable ideas of architecture, power, and politics. So, by having the integrated ideas, they have a certain strive to build a design composing the particular religious-cultural faith on the one side, but the particular political power relations under their main consideration on the other. They have a rational insight to get involved in architecture based on religious and cultural aspects, but to get ready with the political negotiation in the time of occurrence of debate over their architectural products. Surely, they would be aware of architecture irrepressible from other aspects of life, including culture, religion, and politics.

The dilemma in overcoming politics and any related terms also occur among today's architects in Indonesia. This essay has shown that architecture should go beyond the primordial understanding of politics of power, in the sense that it has to be aware of its inseparable link with the politics itself, which consequently makes the nonpolitical framework of architecture is not relevant to understanding the politics of representation in their architectur- 
al products. The long engagement of Javanese-Hindu aspects with architectural designs has led to an understanding of where the architecture is embedded; it is where the power of politics is always involved within. To challenge our primordial understanding of nation-state or nationalism with the boarder issues of architecture, further studies are needed to explore such a dilemma based on the contextualized analysis of socio-economic factors in Java.

\section{E. Conclusion}

The conclusion of this paper elaborates a long-process of negotiation on proper architecture of the mosques in Indonesia involving power of political agency for every event in the past and present. The role of architects is one of the key important agency in spreading architectural styles of mosques, such as kubah (dome), menara (minaret), traditional ornaments, even mihrab direction. Behind these architects do stand many political agencies, ranging from Islamic saints, Dutch government, until President(s) of Indonesia, who together formed a part of the professional as well as political subjects in the particular social and cultural order. Therefore, what constitutes "Indonesian architecture" is in fact politically built under a long dispute until today in the intellectual culture of architectural styles of the mosques.

These mosques were built after a never-ending battle in the relationship between various agencies at present and in the past involving many mixed origins of architectural designs. Some of them become part of Indonesian architectural styles based mosques after a long negotiation in internal circle of community, while others are resulted from a long guerilla and political antagonism among two or more different political agencies. The Javanese-Hindu, Islamic-Betawi, Middle Eastern, or Moorish-European styles in the mosques in Java such Demak, Sukabumi, Istiqlal, Cut Meutia, or even Daan Mogot are achieved through a long negotiation under an inevitable mixture of local-global culture. 
The unprecedented series of debates on architecture and identity since 1400s until today have been more than just a sign of professional insecurity in the age of global-local context; they are also part of endeavors in search for 'true' identity of Indonesian architecture, which might be never achieved as it involves hidden power of agencies in every age. This is perhaps why many architectural studies do not seem to focus much attention on the ideology or politics, or they incline to underestimate any academic studies which establish a possible relationship between power and architecture, between ideology and mosque. It is not that they do not think about the link between architecture and politics, but rather that architecture-either in architect's consciousness or unconsciousness-embodies the inner permanent power and ideological content of the outer designs.

Through the series of architectural cases of the mosque buildings since pre-colonial until post-colonial, this study has explored, despite shortly, the politics of architecture along with the emergence of the double identity of nation-state in Java within the long engagement with Middle Eastern and European styles. The formation and transformation of Javanese Islam, and the architectural form it has taken, is inseparable from the context of social, economic, and political change in Java. Each case needs more exploration, especially in terms of the colonial contributions to the formation of architectural style of mosques in Java, for little sources are available on it. Various nation-wide conferences and papers on colonial period are mostly devoted to share ideas of modern architecture in Sumatera, not in Java.

\section{REFERENCES}

Acciaoli, G. (1985). (1985). "Culture as Art: From Practice to Spectacle in Indonesia”,. Canberra Anthropology, 8(1-2), 148-172. 
Akihary, H. (1990). Architectuur \& Steddebouw in Indonesie 18701970. Zutpen: De Walburg Pers.

Al-Sayyad, Nezar, E. (1992). Forms of Dominance: On the Architecture and Urbanism of the Colonial Enterprise. Aldershot: Avebury.

Amir Hamzah. (2017, April 12). Menyerupai Salib, Pengamat: Bentuk Fisik Masjid Hasyim Asy'ari Menyimpang. Republika, p. 3.

Anderson, Benedic, and O'Gorman, R. (1997). Language and Power Exploring Political Culture in Indonesia. Ithaca, NY: Cornel University Press and Jakarta: Equinox.

Anderson, B. (2006). Language and Power: Exploring Political Cultures in Indonesia. Jakarta and Kuala Lumpur: Equinox.

Anthony D King. (1976). Colonial Urban Development:Culture, Social Power, and Environment. London: Routledge \& Kegan Paul.

Benda, J. (1958). The Crescent and the Rising Sun: Indonesia Islam under the Japanese Occupation 1942-1945. 's-Gravenhage: W. Van Hoeve.

Brenda, Y. (1996). Contesting Space: Power Relations and the Urban Built Environment in Colonial Singapore. Oxford: Oxford University Press.

Cholid, Mohamad, and B. D. (1988). Takdir Mendebat Kubah Masjid. Tempo, 107.

Dijk, K. van. (2007). The Changing Contour of Mosques." In P. J. M. Nas, ed. The Past in the Present: Architecture in Indonesia. Rotterdam: NAi.

Dovey, Kim, \& P. (2010). (2010). “Monas and Merdeka Square. In K. Dovey, ed. Becoming Places: Urbanism/Architecture/Identity/Power (p. 153-165.). London: Routledge.

Errington, S. (1998). The Death of Authentic Primitive Art and Other Tales of Progress. Berkeley: University of California Press. 
Fawaid, A. (2015). Contesting Double Genealogy: Representing Rebellion Ambiguity in Babad Tanah Jawi. International Journal of Heritage of Nusantara, 4(2), 243-260.

Feith, H. (1958). The Wilopo Cabinet 1952-1953: A Turning Point in Post Revolutionary Indonesia. Jakarta: Equinox.

Florida, N. (1995). Writing the Past, Inscribing the Future: History as Prophecy in Colonial Java. Durham: Duke University Press.

Gugler, J. (2004). World Cities beyond the West: Globalization, Development, and Inequality. Cambridge: Cambirdge University Press.

Gwendolyn, W. (1991). The Politics of Urban Design in French Colonial Urbanism. Chicago: Chicago University Press.

Handinoto. (1996). Perkembangan Kota dan Arsitektur Kolonial Belanda di Surabaya (1780-1940). Yogyakarta: Andi Offset.

Hasan, I. (2009). Architecture and the Politics of Identity in Indonesia. The University of Adelaide.

Hitchcock, M. (1997). Indonesia in Miniature. In . In Michael Hitchcock \& Victor T. King, Images of Malay-Indonesia Identity (pp. 227-235). Kuala Lumpur: Oxford University Press.

Hobsbawm, E. (1983). Introduction: Inventing Traditions. Cambridge: Cambridge University Press.

Hong, F. (2006). Sport, Nationalism, and Orientalism: The Asian Games. London: Routledge.

Jessup, H. (1985). Dutch Architectural Visions of the Indonesia Tradition. Muqarnas, No. 3.

Kusno, A. (2000). Behind the Postcolonial: Architecture, Urban Space, and Political Culture in Indonesia. London: Routledge.

Kusno, A. (2003). The Reality of One-Which-Is-Two. Journal of Architectural Education, (57)(1), 57-67.

Legge, J. D. (2003). Soekarno: A Political Biography. Michigan, NY: 
Archipelago Press.

Luqman, A. (1986). Heboh Peninggalan Sunan Kudus. Tempo, 62.

Macdonald, G. M. (1995). Indonesia's Medan Merdeka: National Identity and the Built Environment. Antipode, 27(3), 270-293.

MacRae, G. (2011). Negotiating Architecture Worlds in Indonesia: The Work of Eko Prawoto. The Copenhagen Journal of Asian Studies, 29(1), 92-119.

Maussen, M. J. M. (2009). Dutch Colonialism, Islam and Mosques. In Maussen, Marcel. J. M. Constructing Mosques: The Governance of Islam in France and the Netherlands (pp. 91-106). Amesterdam: University of Amesterdam.

Nas, P. J. M. (1993). Jakarta, City Full of Symbols. In Peter J. M. Nas, ed. Urban Symbolism (pp. 13-37). Leiden: Brill.

Nas, P. J. M. (2003). Ethnic Identity in Urban Architecture: Generations of Architects in Banda Aceh". In Peter J. M. Nas, ed. Indonesian Houses. Leiden: KITLV: 133-153.

O'Neill, H. (1993). Islamic Architecture under the New Order. In Virginia M. Hooker, ed. Culture and Society in New Order Indonesia (pp. 151-165). Oxford: Oxford University Press.

O'Neill, H. (1994). Southeast Asia. In Martin Frishman and Hasan-Uddin Khan, eds. The Mosque: History, Architectural Development and Regional Diversity (pp. 224-240). London: Thames \& Hudson.

Pemberton, J. (1994). On the Subject of "Java." Ithaca: Cornell University Press.

Reid, A. (2002). Island of the Dead. Why do Bataks Erect Tugu? In H. Chambert-Loir \& A. Reid, The Potent Dead: Ancestors, Saints, and Heroes in Contemporary Indonesia (pp. 88102). Sydney and Honolulu: Allen and Unwin and University of Hawaii Press.

Rudi, A. (2017, April 21). (2017). "Mengintip Masjid Raya KH. Hasyim Asy'ari”. Kompas. 21 April: 2. Kompas, p. 2. 
Saliya, Yuswadi, Hariadi, and G. T. (1990). Contemporary Expressions of Islam in Buildings: Indonesian Experience. Paper presented at the seminar on Contemporary Expressions of Islam in Building, sponsored by the Aga Khan Ward for Architecture, Yogyakarta (Oct. 16-19).

Santoso, R. B. (2000). Menegosiasikan Orientasi Simbol Masjid dan Pengaruhnya di Indonesia. Bandung: Institiut Teknologi Bandung.

Sharif, H. M. (2013). Mosques in Islands Southeast Asia, 15th-20th Century. SOAS University of London.

Soekarno. (1990). Bung Karno dan Islam: Kumpulan Pidato tentang Islam, 1953-1966. Jakarta: CV Haji MasAgung.

Steenbrink, K. A. (1993). Dutch Colonialism and Indonesian Islam: Contacts and Conflicts 1596-1950. Amsterdam: Rodopi.

Sukada, B. A. (1999). (1999). "The emergence of a New Indies style." In G. Tjahjono (Ed.), (Indonesian). Jakarta: Archipelago Press.

Waterson, R. (1997). The Living House: An Anthropology of Architecture in South-East Asia. London: Thames and Hudson.

Wiryomartono, B. (2012). The Politics of Development in Indonesia: The Aesthetic Culture and Power Play in Architecture and Urban Design. International Journal of Urban Science, 16(2), 203-223.

Wolters, O. W. (1982). History, Culture, and Religion in Southeast Asian Perspectives. Singapore: Institute of Southeast Asian Studies. 
